\title{
Viktoria POLANSKA
}

Oles Gonchar Dnipropentrovsk National University, Ukraine

\section{The Concept of the Aesthetical Representation of the Political Space}

\section{Idea reprezentacji estetycznej przestrzeni politycznej}

\section{- Abstrakt •}

Istota reprezentacji estetycznej polityki analizowana jest w oparciu o trzy źródła ontologiczne oraz trzy spojrzenia metodologiczne bazujące na estetyce, etyce i psychologii. W artykule poddano analizie ideę reprezentacji estetycznej przestrzeni politycznej oraz sposoby prezentowania politycznej rzeczywistości za pomocą środków estetyzujących. W celu zbadania właściwości sensorycznych estetyzacji polityki jako procesu oraz szeregu zjawisk szczególną uwagę zwrócono na koncepcje symbolu politycznego, metafory politycznej, rytuału politycznego oraz mitu politycznego.

Słowa kluczowe: estetyzacja polityczna, etyka polityczna, psychologia polityczna, symbol polityczny, metafora polityczna, mit polityczny, rytuał polityczny, reprezentacja estetyczna, ocena polityczna

\section{- Abstract •}

The entity of the aesthetical representation of politics is studied basing on three ontological sources and three methodological views on this process: aesthetical, ethical, and psychological. The essence of the aesthetical presentation of the political sphere and the ways of representing political reality by aesthetical facilities are analyzed. The special concepts of a political symbol, the political metaphor, the political ritual, and the political myth are used in the research to discover the sensual parameters of the political aesthetization as the process and collection of the phenomena.

Keywords: political aesthetics, political ethics, political psychology, political symbol, political metaphor, political myth, political ritual, aesthetical representation, political judgment

\section{Introduction}

The aim of this research is to study the concept and the methodology, describing a possibility, potential forms, nature and essence of the aesthetical representation of the political life. 
The tasks connected with this aim are:

- to define the notions of representation, aesthetical representation of the political sphere and political aesthetization;

- to propose the synthetically scientific approach to the study of aesthetical representation of the political sphere;

- to study political aesthetization as a method of political representation, its subject/object structure, functions and forms;

- to analyze the immanent formational and transformational properties of the political aesthetization process.

The research deals with the fields of the political science, philosophy, and psychology and is based on the interdisciplinary approach. First of all, the subject of the research is the content of the political consciousness, the process of the political judgments' formation, and the interrelations between the rational and irrational beginnings of the politics in the process of the political representation in the aesthetical way.

The special concepts of a political symbol, the political metaphor, the political ritual and the political myth are used in the research to discover the sensual parameters of the political aesthetization as the process and collection of the phenomena.

The main problems of this research are the essence of the aesthetical presentation of the political sphere, the ways of representing political reality by aesthetical facilities, the reason of the effective influence of this representation on the process of the political judgments' formation, on the political feelings, beliefs and the political behavior, the subjects and objects of the aesthetical representation, and scientific methods which could be used for the study of the political aesthetization process.

The main hypothesis of the research is the idea of irrational, sensual nature of the political representation, which is realized by the political subjects in the aesthetical forms or the aesthetical technique and manner. The process of the aesthetical representation of the political sphere is the process of the political aesthetization in the forms of symbolization, performance, metaphorization, ritualization, and others.

The entity of the aesthetical representation of the politics is studied basing on three ontological sources and three methodological views on this process: aesthetical, ethical, and psychological. On the one hand, aesthetical representation uses the artistic instrument of art, which has an emotional influence on people and includes such forms as rhetorical constructs with the poetical imaginary meaning, ritual actions with theatralization of political relations, and images and symbolical forms of the political ideas and values. On the other hand, the aesthetical repre- 
sentation has moral functions as a representational structure of a particular moral system which has an explanation and implicit prescriptions for a suitable behavior type within the frames of this moral system. And at last, aesthetical representation has some psychological conditions and factors, and the process of the political reality aesthetization is analyzed as a complex of psychological processes (e.g. attention, perception, emotional reaction, affects and others).

To define this idea the synthetically methodological view is applied based on Framklin Rudolf Ankersmit's concept of aesthetical representation, Hanna Arendt's idea about aesthetical nature of the political judgment, Pierre Bourdieu's concept of the symbolical power, and Rollo May's idea that the psyche works on the basis of similar laws as aesthetics. We use the concepts of political aesthetics, political ethics, political symbol, political metaphor, political myth, and political ritual to describe the sensual features of the political aesthetization, its forms, capacities, and effect on the political consciousness, political judgment, and political behavior.

\section{The Notion of Political Representation}

The examples of the aesthetical representation of the political power can be found in any period throughout the history of mankind. For example, in the Medieval Europe the monarchical processions used to get through the social body like the police patrols do it today. The essence of the representation has changed for centuries, but it has always kept a range of special features and characteristics which are of ontological nature.

The works by H. Arendt, P. Bourdieu, R. May (1994), H. Pitkin (1967), F.R. Ankersmit (1996; 2002), R. Arnheim (1997), V. Bushanski (2009), and M. Edelman (1995) seem to contain a deeper and more detailed analysis of the aesthetical aspects of politics.

Political representation is the process of representation of political power and its attributes at the level of mass consciousness by means of replacing political reality by political symbols and images, providing the presence of power functions and/ /or subjects in the political consciousness forming and circulating political meanings, political judgments, and, finally, political values and behavior patterns. In this article political representation is analysed as aesthetical representation, which can be understood and studied within the frameworks of an interdisciplinary approach, based on the methodology and concepts of political philosophy (political aesthetics and ethics) and political psychology. 
Ankersmit (2002) proposes an idea that representation will always present us with an "aesthetic gap" between the represented and the representation; it is in this aesthetic gap that legitimate political power and all political creativity originate.

Political representation is the process of political power and power aspects reproducing and replacing themselves in political consciousness. The process of political representation is formed and realized in two ways: spontaneous or managed/ /organized and has centers of representative activity and subjectivity with different degrees of the intensity.

The process of political representation has a common ontological origin with the aesthetical representation and is based on the psychological laws used by people to explore the political world being absorbed by it and finally involved in it. Ankersmit thinks that word "representation" can have a relation with both politics and aesthetics (Ankersmit, 2002, p. 33).

\section{Representation and Political Reality}

What is the political reality? We have a lot of answers to this question; most of them are the products of philosophical reflection. Political philosophy and political psychology being different fields of knowledge come to correlated conclusions, according to which a political reality is only real within the frames of its recipients, their perceptive abilities, possibilities, and aims of the representative of it. Thus the personal ability of perception and reflection is the condition of political reality and its activation in the political consciousness.

Edelman's idea of constructive possibilities of aesthetics towards political reality is similar to the idea of F. R. Ankersmit. Edelman supposes that "works of art do not represent $<<$ reality $>$, $<<$ the real word $>>$ or $<<$ everyday life $>>$, even if those terms are taken to carry a specific of meaningful reference. Rather, art creates realities and words. People perceive and conceive in the light of narratives, pictures, and images. That is why art is central to politics, just as it is central to social relationships and to beliefs about nature" (Edelman, 1995, p. 7). According to Ankersmit, political reality is given to us, and then we represent it. He thinks that political representation makes the political reality content (politicians, political ideas, political decisions, and collective will) available or unavailable (Ankersmit, 2002, p. 64).

The result of the aesthetical representation of political reality is the political judgment formation. According to Hanna Arendt's (Curtis, 1999) ideas, political judgment has aesthetical nature, because it is based on the emotional and sensual 
reaction of the viewer of the political scene. Such metaphors as "political theatre", "political scene", "political drama", and others show us the aesthetical emanation of the political phenomena and processes. And this political theatre and scene develop for a viewer with a taste and a judgment's ability, with values and attitudes. Arendt points to the main goal of the aesthetical representation, which is political judgment formation. A political judgment is connected with an aesthetical judgment ontologically, and it is a judgment of taste.

It should be stressed that O'Sullivan points out Derrida's thought, that "the discourse of aesthetics as a discourse of/on representation. Aesthetics is deconstructed, and art becomes a broken promise" (O'Sullivan, 2006, p. 126). The aesthetical nature of representation explicates in the thought of this author, that "...the new media coincide with art: indeed, the new media take on an aesthetic function" (O'Sullivan, 2006, p. 127).

Murrey Edelman's (1995) conception includes the idea that "the ideology of the public, or segment of it, along with the aptitude of spokespersons (lawers, editors, public officials, teachers, and others) for focusing on a particular kind of narrative, shape audience response. Wars become heroic but may also become futile or unnecessary in light of the narratives that depict them" (Edelman, 1995, p. 6).

Activation of the representation process includes psychological processes, working on the principles of the aesthetical exploration of the reality. As to Rollo May's (1994) idea, aesthetical processes work in accordance with psychological laws. Similar ideas are proposed by Rudolf Arhheim (1997) in his conception of art and visual perception. It means that the psyche works on the basis of sensual feelings, perceptions, and valuations of the reality in personal or collective consciousness. The result of these perceptions is the emotional reaction and behaviour acts, formation of values and behaviour patterns. The aesthetical way of the political reality representation is the way of representative organisation of the reality elements for the realization of political power through formation of emotional loyalty and aesthetic legitimacy. Thus, "...a monarch or dictator may be a more successful and dramatic leader, and therefore a better representative, than an elected member of Parliament. Such a leader calls forth emotional loyalties and identification in his followers, the same irrational and affective elements produced by flags and hymns and marching bands. And, of course, representation seen in this need have little of nothing to do with accurate reflection of the popular will, or with enacting laws desired by people" (Pitkin, 1967, p. 106). 


\section{Symbolical Representation of Politics}

The conception of symbolical power of Pierre Bourdieu (Swartz, 1998) includes the idea of a symbol's ability to represent and reproduce social reality in the forms of narrative, special social rituals, signs, rhythms, etc.

Hanna Pitkin conducts an analysis of political representation and its symbolical aspects in the book The Concept of Representation (1967). Pitkin defines human beings as language-using animals, whose behavior is shaped by their ideas. According to the idea of this research what they do and how they do it depends upon how they see themselves and their world, and this in turn depends upon the concepts through which they see. Pitkin considers the next questions as intimately connected: what "representation" means and how to represent. This scientist stresses the significance of the category as "symbolic" for political thought, we have to understand the way in which symbols represent (Pitkin, 1967, p. 93).

It is necessary to note that Pitkin (1967) pays attention to the differences between representing and symbolizing but studies the symbolical manner of representation. M. Yampolskiy (2004) has a similar idea that symbolizing is not the same as presentation.

Symbolical representation is a representation by symbols, rituals, myths, and metaphors. It realized within the symbolical politics providing. Symbolical representation is based on the properties of a symbol. But "symbols, in contrast, are often said to represent their referent... The fish was a symbol of Christ, but not a representation of him. The artist who painted a fish was not representing (showing) Christ as a fish; he was making no allegations about Christ's appearance. Unlike representations, symbols are not likenesses of their referents, and do not resemble them. They make no allegations about what they symbolize, but rather suggest or express it" (Pitkin, 1967, p. 94).

Pitkin argues that the symbol is, roughly, a substitute for what it represents; but a symbol is not a substitute for what it symbolizes. "Symbols are not proxy for their objects, but are vehicles for the conception of what they symbolize" (Pitkin, 1967, p. 97). A symbol cannot be a substitute of a political object, but can be an embodiment of some political ideas, programs, values or even political person. "...The actions of the head of state are merely ceremonial that we consider him as a symbol [...] Such a leader may endanger his status as symbol and embodiment of the whole people if he becomes involved in active, partisan politics" (Pitkin, 1967, p. 102) .

Thus, the aesthetical representation of politics is not symbolical, but contains its features and abilities. Aesthetical representation is not an imitation of political 
reality. Ankersmit (2002) stresses that aesthetical representation is not mimetic of political reality, but a reproduction of the political reality in the political consciousness.

\section{The Function of Aesthetical Representation of Politics}

Aesthetical representation of politics has some important functions arising out of the political and aesthetical nature of this process: substitution of the political power, political or social integration and disintegration, identification, and political power presence procuring. Thus $\mathrm{H}$. Pitkin supposes that "the existence of representation is to be measured by the state of mind, the condition of satisfaction or belief, of certain people, be they the represented or the audience. This makes representation a kind of two-way correspondence; it <<concerns the agreement prevailing between ruler and ruler>>" (Pitkin, 1967, p. 106).

According the idea of P. Bourdieu (Swartz, 1998), symbols are the instruments of "social integration" per excellence, the instruments of cognition and communication. Symbols promote an appearance of consensus as to social world and social order. And not only symbols but also images, performances, rituals, and other aesthetical facilities of political representations can have this integrating function.

One more special function of aesthetization of politics is the creation of political phenomena in real life by creating them in political consciousness. Thus, if the goal is to create a nation, "a single dramatic symbol can achieve this much more effectively than a whole legislature of representatives" (Pitkin, 1967, p. 107).

Murrey Edelman thinks that the models, scenarios, narratives, and images into which audiences for political news translate that news are social capital, not individual intentions. "They come from works of art in all genres: novels, paintings, stories, films, dramas, television sitcoms, striking rumors, even memorable jokes" (Edelman, 1995, p. 3).

According to Edelman, the works of art generate the ideas about leadership, honor, power, bravery, cowardice, altruism, dangers, authority, and other political ideas as well as fantasies, desires about the future that people typically assume to be reflections of their own observations and reasoning. "Art forms are incorporated into governmental processes themselves, influencing authority and subordination. Art creates contestable categorizations of public issues that reflect particular conceptions and particular ways of experiencing contemporary times. And art shapes, displaces, and sometimes supersedes cherished influences upon public policy like voting and lobbying" (Edelman, 1995, p. 3). "Exposure and reaction 
to particular art forms is certainly selective, reflecting their degree of availability to various people as well as the intentions and biases of individuals and groups. But even when art reinforces preexisting prejudices, its contribution of images and other symbols is vital" (Edelman, 1995, p. 6).

At last, special addition should be paid to the fact that the results of political representation can take the form of a political concept built in the field of political discourse. Symbols can also take a form of a metaphor and provide the nominalization of political objects, giving them new sense. Thus, aesthetical representation by metaphorization has the function of political discourse organization.

\section{Conclusions}

The discussion as to the essence of the political, aesthetical, and symbolical representation is studied in this article, and it is necessary to note that the concept of aesthetical representation of politics reconciles different approaches.

Political representation is the substitution and reproduction of the reality in the political consciousness. It means that political reality only exists in a subjective form and could be activated in the process of contact with personal consciousness. But political presentation is possible through the collective consciousness phenomenon, which required the simplification and elimination of the personal (subjective) attitudes and further creation of the useful conditions for perception of the substitution of the reality like the mass communication processes.

Politics can be considered as a text or discourse of the politics. Politics as a text should be researched by the viewing of the semiotic methodology, constructivism, and content-analysis. But, the results of this research have to be supplemented by the political-aesthetical approach viewing the content of the political discourse is the only top of sensual and valuation iceberg.

People perceive politics not only by rational analysis but also in an irrational way, by feelings, emotions, affects, and impressions, which become factors in political judgments and political values' formation. The ways and means by which politics is represented are possible to be studied. The research contains the methodological approach to realize it.

The political representation of the present time is directed at the representation of the politicians, political ideas, political decisions, political programs, and the state, which make up the content of the political life. This content has to be represented, not only by explanation through rational notions and arguments, but also by images, symbols, metaphors, rituals, and other irrational forms. 
Philosophy gives us the instruments to understand the moral limits of this process, but the aesthetical entity seems to be prior to morality. Political representation has a moral measurement, because the object of the representation is positioned in the system of political values and norms by the process of the political judgments' formation. The process of the political judgments' formation is the main goal of the political representation.

The psychology of perception and evaluation gives us the explanation of the process of viewing and understanding of the political reality by the individual and collective consciousness. Psychology can explain how the aesthetical processes work.

\section{References:}

Ankersmit, F. R. (1996). Aesthetic Politics: Political Philosophy Beyond Fact and Value. Stanford: Stanford University Press.

Ankersmit, F. R. (2002). Political Representation. Stanford: Stanford University Press.

Arnheim, R. (1997). Art and Visual Perception. A Psychology of the Creative Eye. The New Version. Berkely, Los Angeles, London: University of California Press.

Bushansky, V. V. (2009). The Aesthetics of Political Power. Kyiv: Parapan.

Curtis, K. (1999). Our Sense of the Real: Aesthetic Experience and Arendtian Politics. Ithaca and London: Cornell University Press.

Edelman, M. (1995). From Art to Politics: How Artistic Creations Shape Political Conceptions. Chicago and London: The University of Chicago Press.

May, R. (1994). The Courage to Create. New York: W. W. Norton.

O'Sullivan, S. (2001). The Aesthetics of Affect. Thinking Art Beyond Representation. "ANGELAKI" Journal of the Theoretical Humanities, Vol. 6., No 3, 125-135.

Pitkin, H. F. (1967). The Concept of Representation. Los Angeles, CA: University of California Press.

Swartz, D. (1998). Culture \& Power: The Sociology of Pierre Bourdieu. Chicago: University of Chicago Press.

Yampolsky, M. (2004). The Physiology of the Symbolical. Book 1. Leviathan's Comeback: Political Theology, Power Representation and the End of the Old Regime. Moscow: New literature review. 